\title{
Influences of mature Pinus nigra plantations on the floristic- vegetational composition along an altitudinal gradient in the central Apennines, Italy
}

\author{
Marina Allegrezza ${ }^{(1)}$, \\ Simone Pesaresi ${ }^{(1)}$, \\ Sandro Ballelli ${ }^{(2)}$, \\ Giulio Tesei ${ }^{(1)}$, \\ Cecilia Ottaviani ${ }^{(1)}$
}

\begin{abstract}
Plantations of conifers are widespread in Europe, often occurring outside of their native range. Reduction in species richness linked to increases in altitude has been previously reported for natural forests, although there is a lack of specific studies for mature pine plantations in both the Apennines and Europe. The aim of this study was to quantify the long-term effects of the extensive Pinus nigra plantations carried out between 1900 and 1956 in protected areas on floristic richness, species composition, and ecological traits of the understorey vegetation. We compared 20 mature pine plantations selected along an altitudinal gradient (700-1700 $\mathrm{m}$ a.s.l.) with neighbouring deciduous natural forests dominated by Ostrya carpinifolia and Fagus sylvatica, which represent the most widespread forest types in the central Apennines. The results showed that floristic richness follows two distinct altitude trends in pine plantations and natural forests. A strong reduction in species richness with elevation was observed in the natural forests, as well as a consequent increase in the local contribution to beta diversity, with a turnover of the ecological traits of the species. Contrastingly, no significant changes in richness and beta diversity were found for pine plantations in the same altitude range. Indeed, mature pine plantations up to $1400-1500 \mathrm{~m}$ a.s.l. showed the presence of many heliophilous and thermophilous species that are usually distributed at lower elevation. We discuss how such pine plantations can mitigate the effect of increasing altitude which is usually observed in the natural forests, slowing down the typical diversification of the forest communities along the altitudinal gradient.
\end{abstract}

Keywords: Pinus nigra Plantations, Forest Origin, Richness, Beta-diversity, Altitudinal Gradient, Canopy Filter, Protected Areas, Apennines $\times 10^{3}$ ha, respectively (FAO 2006).

The conifer species used in these forestation activities were often established outside of their native range and on nonforested land originally covered by broadleaved species. The most widespread nonnative tree genera and species were pines (Pinus spp.), whereby species from this genus currently cover approximately 1.7 million ha in Europe (Forest Europe 2015). Recently, the main focus has been on the conversion of pine plantations into natural
(1) Department of Agricultural, Food and Environmental Sciences, Polytechnic University of Marche, v. Brecce Bianche, I-60131 Ancona (Italy); (2) School of Environmental Sciences, University of Camerino, v. Pontoni 5, I-62032 Camerino, MC (Italy)

@ Marina Allegrezza (m.allegrezza@staff.univpm.it)

Received: Aug 09, 2019 - Accepted: Apr 30, 2020

Citation: Allegrezza M, Pesaresi S, Ballelli S, Tesei G, Ottaviani C (2020). Influences of mature Pinus nigra plantations on the floristic-vegetational composition along an altitudinal gradient in the central Apennines, Italy. iForest 13: 279-285. - doi: 10.3832/ifor3215-013 [online 2020-07-03]

Communicated by: Matteo Garbarino broad-leaved forests. For ecological and economic reasons, the integration of natural regeneration processes into conversion management is considered an important task (Zerbe 2002).

Many studies of these forest communities were focused on silvicultural aspects, and some of these were aimed at renaturalisation (Mosandl \& Küssner 1999). Although less numerous, vegetation studies have also been published for European countries, such as those on Pinus pinaster and Pinus halepensis in Italy (Chiarucci \& De Dominicis 1995, Baiocco et al. 1996). Finally, many studies have highlighted the effects of pine plantations on biodiversity. The biodiversity of these communities depends on numerous abiotic and biotic ecological factors, such as climate, former land cover, tree layer cover, competitive/facilitative species interactions, management, and distance from natural forests (Carnus et al. 2006, Gómez-Aparicio et al. 2009). It has been shown that forests of artificial origin have lower species richness than natural forests (Barlow et al. 2007), although some authors highlighted the importance of pine plantations in biodiversity conservation and restoration of forest species through 
positive microclimate and biotic interac tions (Kunstler et al. 2007). In particular, mature pine plantations established on previously forested lands are generally expected to support higher levels of diversity, and, in the long term, they can develop a structural complexity that is similar to that of native forests (Carnus et al. 2006, Brockerhoff et al. 2008, Bremer \& Farley 2010, Ottaviani et al. 2015), as their favourable microclimates, litter and humus layers are more conducive to native plant colonisation (Geldenhuys 1997, Brockerhoff et al. 2008).

So far, a few studied focused on the biodiversity of forest plantations along environmental gradients. For natural forests, a decline in species richness has been demonstrated with increasing altitude, both in tropical forests (Vazquez-García \& Givnish 1998) and in temperate forests (Sharma et al. 2009, Sabatini et al. 2018, Scolastr et al. 2014), with rare exceptions for temperate fire-beech forests in central Europe (Hrivnák et al. 2014). Specific studied on pine plantations are generally lacking for both the Italian Apennines and Europe, except for those of Gómez-Aparicio et al. (2009) on Pinus spp. for the Iberian Peninsula. These authors investigated the biodiversity of pine plantations along an altitudinal gradient with a Mediterranean climate on the Sierra Nevada, showing that species richness decreased with increasing altitude following a Gaussian pattern (Gómez-Aparicio et al. 2009), similar to that seen for the natural forests of the western Mediter ranean (Olthoff et al. 2016). Their pine plantations also appeared to be in line with the general distribution of species richness commonly reported in the literature (Rahbek 1995).

In Italy, Pinus nigra s.l. has been widely used in forestation activities since the early 1900s (Amorini \& Fabbio 1992, Nocentin 1999). In particular, Pinus nigra subsp. nigra has been employed until the 1950s for ex tensive afforestation of non-forested areas on the Apennines at elevation from $\sim 600$ to $1600 \mathrm{~m}$ a.s.l., with the aim of guarantee ing hydrogeological protection (so as to quickly cover the soil) and satisfying the socio-economic needs of local populations (timber production, new jobs, qualified manpower, etc.), especially in mountain marginal areas (Cantiani et al. 2018). In this context, the choice of establishing Pinus nigra subsp. nigra outside of its native range (i.e., outside of its south-eastern Europe distribution) in areas with the potential for deciduous forests was favoured by its ease of growth in the nursery and its distinctly pioneering characteristics (Cantiani et al. 2005).

Pine-dominated forest communities are widespread along the Apennines, covering about 28,000 ha from Liguria in the north to Calabria in the south (INFC 2007). This is especially the case for montane southern slopes, where the anthropic effects over the centuries have been more intense, as demonstrated in a recent study on the current limits of forests in the Apennines (Bonanomi et al. 2018). In general, these artificial stands were not managed, thus they underwent the natural dynamic processes of restoration by the native vegetation, as it is particularly obvious in mature pine plantations (Allegrezza et al. 2013, Ottaviani et al. 2015). Additionally, in some cases mature pine plantations host rare forest plant species of biogeographic interest in the Apennines, such as the orchid Goodyera repens (Allegrezza et al. 2014) which is at the southern limit of its native range in Europe. Furthermore, due to their current structure and species composition, these pine plantations are the preferential habitat for many species of birds, including the finch Loxia curvirostra L. which is included in Annex II of Habitats Directive 92/10 (Benkman \& Parchman 2009).

The aim of this study was to investigate the extensive Pinus nigra plantations carried out between 1900 and 1956 on nonforested areas in the Apennines with a temperate climate and the potential for deciduous forests. We quantified the longterm effects of pine plantations on species richness, floristic compositional diversification (i.e., beta-diversity), and ecological traits of the vegetation (i.e., local contributions to beta-diversity, LCBD). This was achieved by comparing pine plantations along an altitudinal gradient of $1000 \mathrm{~m}$ (from 700 to $1700 \mathrm{~m}$ a.s.l.) with neighbouring deciduous natural forests, which are dominated by Ostrya carpinifolia and Fagus sylvatica and represent the most widespread forest vegetation community in the Apennines. We expected pine plantations to show a lower biodiversity in comparison to adjacent natural forests, and this trend to be affected by the altitude.

\section{Material and methods}

\section{Study site selection and description}

We preliminarily identified 70 sites across the extensive areas of Pinus nigra plantations established between 1900 and 1956 in a sector of the central Apennines (central Italy) between $43^{\circ} 47^{\prime} 46.69^{\prime \prime} \mathrm{N}$ and $41^{\circ} 46^{\prime}$ $47.43^{\prime \prime} \mathrm{N}$ of latitude and $12^{\circ} 19^{\prime} 59.65^{\prime \prime} \mathrm{E}$ and $13^{\circ} 55^{\prime} 59.70^{\prime \prime} \mathrm{E}$ of longitude. This was achieved through the analysis of cartographic documents of the Italian Military Geographic Institute and using historical photographs (http://www.igmi.org).

Site selection was carried out based on a series of parameters related to the diversity and floristic composition of pine plantations (Carnus et al. 2006, Gómez-Aparicio et al. 2009): time of planting; type of planting (pure or mixed); management; tree layer coverage; and distance from native forests. Preliminary analyses using a Geographic Information System (ArcGIS ${ }^{\oplus}$ v. 10.0 - ESRI, Redlands, CA, USA) allowed to select pine plantation sites showing the following characteristics (see also Tab. S1 in the Supplementary material): pure, unman- aged stands with at least 50\% tree cover, and the presence nearby (distance between surveyed plots: 170.8 to $8828.9 \mathrm{~m}$ ) of a mature natural forest dominated by Ostrya carpinifolia or Fagus sylvatica, defined as under the same topographic conditions (e.g., calcareous lithology, prevalent southern aspect).

These natural forests are the most extensive and widespread in the central Apennines (Blasi 2010), as they cover $8.1 \%$ and $9.8 \%$ of the total forest area for Ostrya carpinifolia and Fagus sylvatica, respectively (INFC 2007). In syntaxonomic terms (Biondi et al. 2014), the forest communities that are dominated by Ostrya carpinifolia mainly refer to the plant association Scutellario columnae-Ostryetum carpinifoliae Pedrotti, Ballelli \& Biondi ex Pedrotti, Ballelli, Biondi, Cortini Pedrotti \& Orsomando 1980, which belongs to the endemic Apennines suballiance Laburno anagyroidis-Ostryenion carpinifoliae (Ubaldi 1995) Blasi, Di Pietro \& Filesi 2004 - forest communities of Ostrya carpinifolia, Fraxinus ornus, Quercus cerris, Quercus pubescens, which develop in the areas with a mesotemperate thermotype, along the entire Apennine chain up to 9001100 m s.l.m. -, and to the alliance Carpinion orientalis, the order Quercetalia pubescenti-petraeae, and the class Querco roboris-Fagetea sylvaticae. The Fagus sylvatica forests are referred to the plant association Lathyro veneti-Fagetum sylvaticae Biondi et al. ex Biondi, Casavecchia, Pinzi, Allegrezza \& Baldoni 2013 - thermophilous, macrotherm Fagus sylvatica forest characterized by the presence of plants of the hilly bioclimatic belt such as Sorbus aria, Ostrya carpinifolia, Hepatica nobilis, etc., which are mixed with those typical of the montane bioclimatic belt. It is distributed in the central Apennines in the lower supratemperate thermotype from 600(1100)1200(1600) $\mathrm{m}$ a.s.l. These beech forest communities represent the transitional aspect between the Ostrya carpinifolia forests of the plant association Scutellario columnae-Ostryetum carpinifoliae (suballiance Laburno-Ostryenion) and the microtherm beech forests of the plant association Cardamino kitaibelii-Fagetum sylvaticae (suballiance Cardamino kitaibelii-Fagenion sylvaticae), that is present at higher altitudes (>1300-1600 m a.s.l.). The plant association Lathyro veneti-Fagetum sylvaticae belongs to the endemic central Apennines suballiance Lathyro veneti-Fagenion sylvaticae, of the alliance Aremonio-Fagion sylvaticae, the order Fagetalia sylvaticae, and the class Querco roboris-Fagetea sylvaticae. Commonly, for the southern slopes, the Ostrya carpinifolia forests are replaced by Fagus sylvatica forests above $1100 \mathrm{~m}$ (Blasi 2010).

We finally selected 20 sites, each including a pine plantation and a neighbouring natural forest (Fig. 1): 10 sites at altitude $<1100 \mathrm{~m}$ a.s.l., and 10 sites at altitude $>1100$ m a.s.l. (Tab. S1 in Supplementary material). The selected sites were located within $\mathrm{Na}$ - 
tional Parks (Monti Sibillini National Park, Gran Sasso and Monti della Laga National Park, Majella National Park, Abruzzo, Lazio and Molise National Park), Regional Natural Parks (Sasso Simone and Simoncello Regional Natural Park, Gola della Rossa and Frasassi Regional Natural Park, SirenteVelino Regional Natural Park) and Natura 2000 areas (see Tab. S1 in Supplementary Materials).

Tab. 1 shows the mean values of altitudes, annual temperatures, annual precipitation, and bioclimatic diagnoses for the sites analysed in this study, in relation to the low (<1100 $\mathrm{m}$ a.s.l.) and high (>1100 $\mathrm{m}$ a.s.l.) elevation.

\section{Data collection}

At each selected site, we identified two plots (one for a pine plantation and one for a natural forest), for a total of 40 plots: 20 plots at <1100 $\mathrm{m}$ a.s.l. (10 plots, pine plantations; 10 plots, natural forests) and 20 plots at $>1100 \mathrm{~m}$ a.s.l. (10 plots, pine plantations; 10 plots natural forests). The plot size was $300 \mathrm{~m}^{2}$. For each plot, all of the vascular plant species were recorded, and their cover-abundance estimated according to the Braun-Blanquet method (1928). The seven-point Braun-Blanquet scale was used according to the following cover values: with cover $<1 \%$ ( $r$, very few individuals; + , few individuals); and with cover $\geq 1 \%$ ( $1: 1 \%$ to $5 \%$; 2 : $5 \%$ to $25 \% ; 3: 25 \%$ to $50 \% ; 4: 50 \%$ to $75 \% ; 5: 75 \%$ to $100 \%)$. The vegetation surveys were repeated in spring and late summer, to capture the seasonal variability of the vegetation. A community matrix of 40 surveys $\times 267$ species was obtained. The species nomenclature follows the check-list of Italian flora (Bartolucci et al. 2018). In addition, the following ecological traits of the plant species were considered: (i) the biological form (Pignatti 1982); (ii) the Ellenberg's indicator value (Light, Temperature, Continentality, Moisture, Reaction of soil, Nitrogen - Ellenberg et al. 1992, Pignatti et al. 2005); and (iii) the social behaviour type (SBTs: 1, beech forest specialist species; 2, forest generalist species; 3, no forest species; 4, marginal species [exotics, weeds, members of ruderal or agricultural communities]; 5, gap species [linked to forest edges and gaps]), according to Bartha et al. (2008). We multiplied the "surveys $x$ species cover-abundance values" matrix (species cover-abundance values were scaled to presence/absence: 0,1 ) with the "species $x$ ecological trait values" matrix (trait values standardised into range 0-1), obtaining the quantitative "surveys $\times$ ecological traits" (with the proportion for each biological form and SBT and the mean Ellenberg indicator values).

The complete plant list of the "species $x$ ecological trait values" and the species frequencies (\%) within each plot group (low/ high altitude pine plantations; low/ high altitude natural forests) are reported in Tab. S2 (Supplementary material).

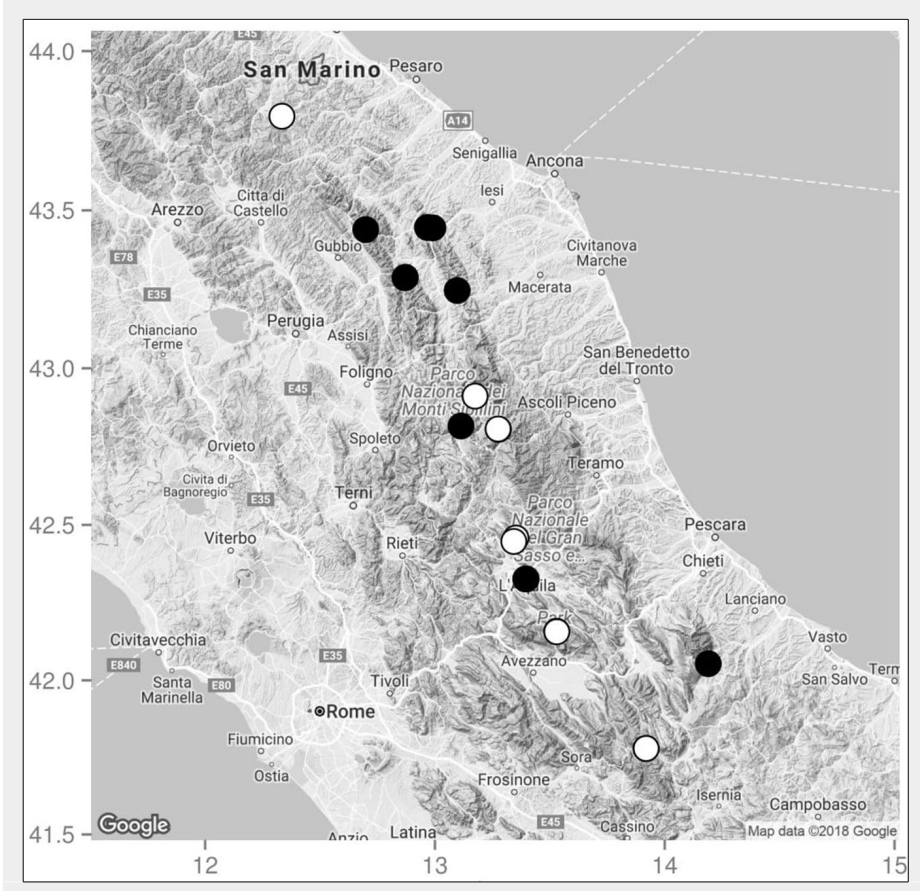

Fig. 1 - Location of the 20 selected Pinus nigra plantations established between 1900 and 1956, with neighbouring natural forests for comparison. Black circles: sites with altitude $<1100 \mathrm{~m}$ a.s.l. (Ostrya carpinifolia natural forests); white circles: sites with altitude $>1100 \mathrm{~m}$ a.s.l. (Fagus sylvatica natural forests). Based on the physical Google Maps ${ }^{\top M}$.

\section{Data analysis}

The local contributions to beta-diversity (LCBD) was estimated based on the "surveys $\times$ species cover-abundance values" matrix (Legendre \& De Cáceres 2013) using the Hellinger-transformed abundance data, with the calculation of the richness of the plots. The LCBD analysis measures the individual contributions of each plot (i.e., the LCBD plot as percentages) to the total beta diversity (i.e., the total variation of the matrix of the Hellinger surveys $\times$ transformed species abundance). The LCBD value is a comparative indicator of the ecological uniqueness of the plot in terms of its community composition. Plots with a mean species composition will have LCBD values close to zero, while large LCBD values can indicate unusual species compositions (Legendre \& De Cáceres 2013).

The effect of the main environmental factors (forest origin, ORIG: pine plantation/ natural forest; altitude, ALT: low/high; and their interaction effect) on LCBD and richness were tested through a factorial twoway ANOVA. Before the analysis, all varimoscedasticity, and transformed when necessary.

We also tested the effect of forest origin, altitude and their interaction on the ecological traits by applying the two-way multivariate ANOVA (MANOVA) with redundancy analysis (RDA) using the above factors and their interaction as explanatory variables and the variables of the "surveys x ecological traits" matrix as the response variables. The factors were coded using Helmert contrasts as the orthogonal (this allowed the correct $F$ values to be obtained). We previously checked the multivariate homogeneity of the within-group covariance using the distance-based tests suggested by Anderson (2006). The statistical significance of each main factor and their interaction was assessed based on 10,000 permutations (free for interaction, stratified for main factor). With respect to the classical parametric MANOVA, the RDA provides a graphical representation of the results (i.e., the RDA triplot; for further details, see Borcard et al. 2011). We plotted ables were tested for normality and ho-

Tab. 1 - Mean climatic and bioclimatic data for the 20 sites with Pinus nigra plantations used in this study, as derived from the bioclimatic map of Italy (Pesaresi et al. 2014, Pesaresi et al. 2017). Low altitude: 10 sites at altitude $<1100 \mathrm{~m}$ a.s.l., where the neighbouring natural forests are dominated by Ostrya carpinifolia. High altitude: 10 sites at altitude $>1100 \mathrm{~m}$ a.s.l., where the neighbouring natural forests are dominated by Fagus sylvatica. (a): Bioclimatic diagnosis according to Rivas-Martinez et al. (2011).

\begin{tabular}{lcc}
\hline \multirow{2}{*}{ Variable } & \multicolumn{2}{c}{ Altitude } \\
\cline { 2 - 3 } & Low & High \\
\hline Mean site altitude $(\mathrm{m}$. a.s.l.) & $770 \pm 100$ & $1324 \pm 171$ \\
\hline Mean annual temperature $\left({ }^{\circ} \mathrm{C}\right)$ & $11.4 \pm 1.07$ & $8 \pm 0.95$ \\
\hline Mean annual precipitation $(\mathrm{mm})$ & $1070 \pm 200$ & $1100 \pm 157$ \\
\hline Bioclimatic diagnosis ${ }^{(a)}$ & $\begin{array}{c}\text { Temperate, low } \\
\text { supratemperate, } \\
\text { upper humid }\end{array}$ & $\begin{array}{c}\text { Temperate, upper } \\
\text { supratemperate, } \\
\text { low humid }\end{array}$ \\
\hline
\end{tabular}



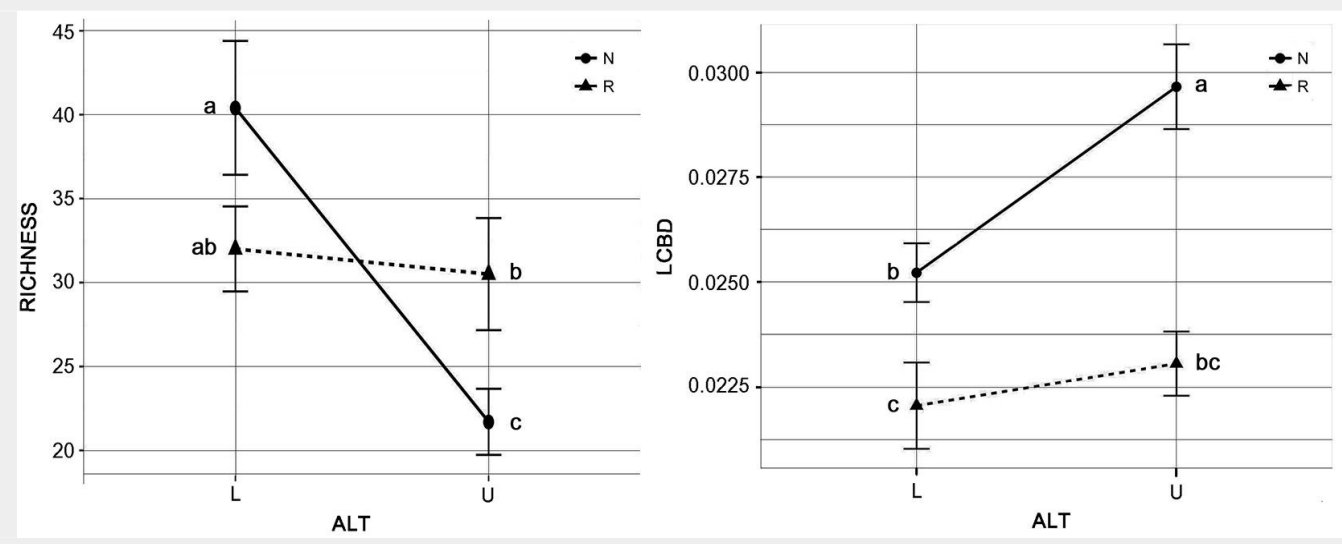

Fig. 2 - Interaction plot of the local contributions to the beta diversity (LCBD) and the richness values of the forest origin vs. altitude. (a) Richness; (b) LCBD. (ALT): altitude, $m$ a.s.l. (L: ALT < 1100; U: ALT > 1100); (ORIG): forest origin $(\mathrm{N}$, natural forest; R, pine plantation). Data are means \pm standard error. Different letters indicate statistically significant differences $(P<0.05)$ after posthoc Duncan tests.

the final RDA triplot with the site-weighted sum scores related to the factor levels and the arrows of the mean ecological trait scores (those with at least 30\% variance explained). Significant differences were evaluated at $\alpha=0.05$ level.

\section{Results}

The analyzed plots had species richness values ranging from 15 to 40 . The pine plantations had a mean richness of 31.2. The mean richness values for the low- and highaltitude plantations were 32.0 and 30.5 (i.e., $5 \%$ difference in mean richness between low and high altitudes). The natural forests had a similar mean richness of 31.0. However, the means of the low and high altitudes for the natural forests were 40.4 and 21.7 (i.e., $46 \%$ difference in mean richness between low and high altitudes - Fig. 2a). The two-way ANOVA showed significant interaction effects between altitude (ALT) and forest origin (ORIG), with $16 \%$ of the total variation (Tab. 2). Therefore, the effects of ALT (22\%) depended on the level of the ORIG factor. Pine plantations and natural forests had two distinct altitude trends (Fig. 2). Post-hoc tests showed a significant difference between the low and high altitude zones for the natural forests, with strong reduction in the richness with increasing the elevation, while no effects of altitude were observed on pine plantations (Fig. 2a).

The two-way ANOVA of the LCBD plots showed significant effects of the main factors ORIG and ALT, which explained 38\% and $12 \%$ of the total variation, respectively, though the interaction effects was not significant $(p=0.06-$ Tab. 2). Fig. $2 b$ shows the altitude trends for pine plantations and natural forests, with a greater increase for the natural forests. The post-hoc tests showed significant differences between the low and high altitude zones for the natural forests, with marked increase in the LCBD means, while for pine plantations, the altitude did not show any significant effects (Fig. 2b).

The results of the two-way MANOVA-RDA indicated that ALT and ORIC have a significant effect on the variation in ecological traits (the "surveys $\times$ ecological traits" matrix), while the interaction effect was not

Tab. 2 - ANOVA summary for the local contributions to beta diversity (LCBD) and species richness of pine plantations and natural forests. (ORIG): origin (pine plantation or natural forest); (ALT): altitude (low, <1100 m a.s.l.; high, >1100 $\mathrm{m}$ a.s.I.); (MS): mean square; (df): degrees of freedom.

\begin{tabular}{lclllllllll}
\hline \multirow{2}{*}{ Factor } & df & \multicolumn{1}{l}{ LCBD } & \multicolumn{7}{c}{ Richness } \\
\cline { 3 - 11 } & & MS & F & p & $\begin{array}{l}\text { Effect } \\
\text { size }\end{array}$ & MS & F & p & $\begin{array}{l}\text { Effect } \\
\text { size }\end{array}$ \\
\hline ORIG & 1 & $2.39 \mathrm{e}-04$ & 30.28 & $<0.001$ & 0.38 & 0.02 & 0.22 & 0.64 & 0.00 \\
\hline ALT & 1 & $7.38 \mathrm{e}-05$ & 9.36 & 0.004 & 0.12 & 1.12 & 12.42 & 0.001 & 0.22 \\
\hline ORIG $\times$ ALT & 1 & $2.94 \mathrm{e}-05$ & 3.73 & 0.061 & 0.05 & 0.68 & 7.6 & 0.009 & 0.14 \\
\hline Residuals & 36 & $2.84 \mathrm{e}-04$ & - & - & 0.45 & 3.25 & - & - & 0.64 \\
\hline
\end{tabular}

Tab. 3 - Two-way MANOVA summary for the redundancy analysis carried out on pine plantations and natural forests vegetation data. (ORIG): origin (pine plantation, natural forest); (ALT): altitude (low, <1100 m a.s.l.; high, >1100 $\mathrm{m}$ a.s.l.); (Adj-r ${ }^{2}$ ): adjusted $\mathrm{r}^{2}$ (expressed as percentage values).

\begin{tabular}{lccc}
\hline Factor & Adj-r $\mathbf{r}^{2}$ & $\mathbf{F}$ & $\mathbf{P}$ \\
\hline ALT & $18 \%$ & 11.169 & 0.001 \\
\hline ORIG & $14 \%$ & 89.055 & 0.001 \\
\hline ALT $\times$ ORIG & $2 \%$ & 2.03 & 0.078 \\
\hline
\end{tabular}

significant ( $p>0.05)$. The factors ALT and ORIG explained $18 \%$ and $14 \%$, respectively, of the total variation in ecological traits (Tab. 3).

Fig. 3 shows the RDA triplot of the twoway MANOVA-RDA model. The two axes, RDA1 and RDA2, both showed significance ( $p=0.001$ and $p=0.003$, respectively). ALT and ORIG were the significant factors that affected the whole trait variability analysed. The RDA1 axis was predominantly linked to ALT, and represents $61 \%$ of the explained variation. A clear separation between the forests at low altitude and the natural forests at high altitude is obvious along the RDA 1 axis. The positive part of RDA 1 axis includes the pine plantations and natural forests at low altitude. Both of these forests had high proportions of phanerophytes and a high mean temperature, as inferred from the mean Ellenberg's indicator values. Contrastingly, the negative part of the RDA1 axis mainly includes the natural forests at high altitude, which had large proportions of geophytes (e.g., Hepatica nobilis, Cyclamen hederifolium, Epipactis mulleri), SBT1 (beech forest specialist species), and a high Ellenberg's indicator values for moisture and nitrogen. For example, Adoxa moschatellina and Cephalanthera damasonium are geophyte, specialist forest species, that are shade tolerant and sciophilous, and that demand nutrients and moisture present in the high-altitude natural forests.

The RDA2 axis was predominantly linked to ORIG, and represents $32 \%$ of the explained variation. A separation between pine plantations and natural forests is quite evident along the RDA2 axis. The negative part of the RDA2 axis includes natural forests that had high mean proportions of SBT2 (generalist forest species) and geophytes, with high Ellenberg's indicator values for moisture and nitrogen. The positive part of the RDA2 axis mainly includes the pine plantations at high altitude that had high proportions of STB4 (i.e., marginal species - exotics, weeds or members of ruderal or agricultural communities, such as Arabis hirsuta and Heracleum sphondylium subsp. pyrenaicum) and high Ellenberg's indicator values for light (e.g., Cytisophyllum sessilifolium). 
Fig. 3 - Redundancy analysis triplot of the MANOVA model of the ecological trait means of the data constrained to the factors of forest origin (R: pine plantations; $\mathrm{N}$ : natural forests) and altitude (L: low, <1100 $\mathrm{m}$ a.s.l; $\mathrm{U}$ : high, $>1100 \mathrm{~m}$ a.s.l). The ecological traits with at least $30 \%$ of variance explained by the model are superimposed. Biological forms: T, therophytes; G, geophytes; Ph, phanerophytes. Ellenberg's indicator values: L, Light; T, Temperature; U, Moisture; N, Nitrogen; Social Behaviour Types: SBT1, beech forest specialist species; SBT 2, forest generalist species; SBT4, marginal species.

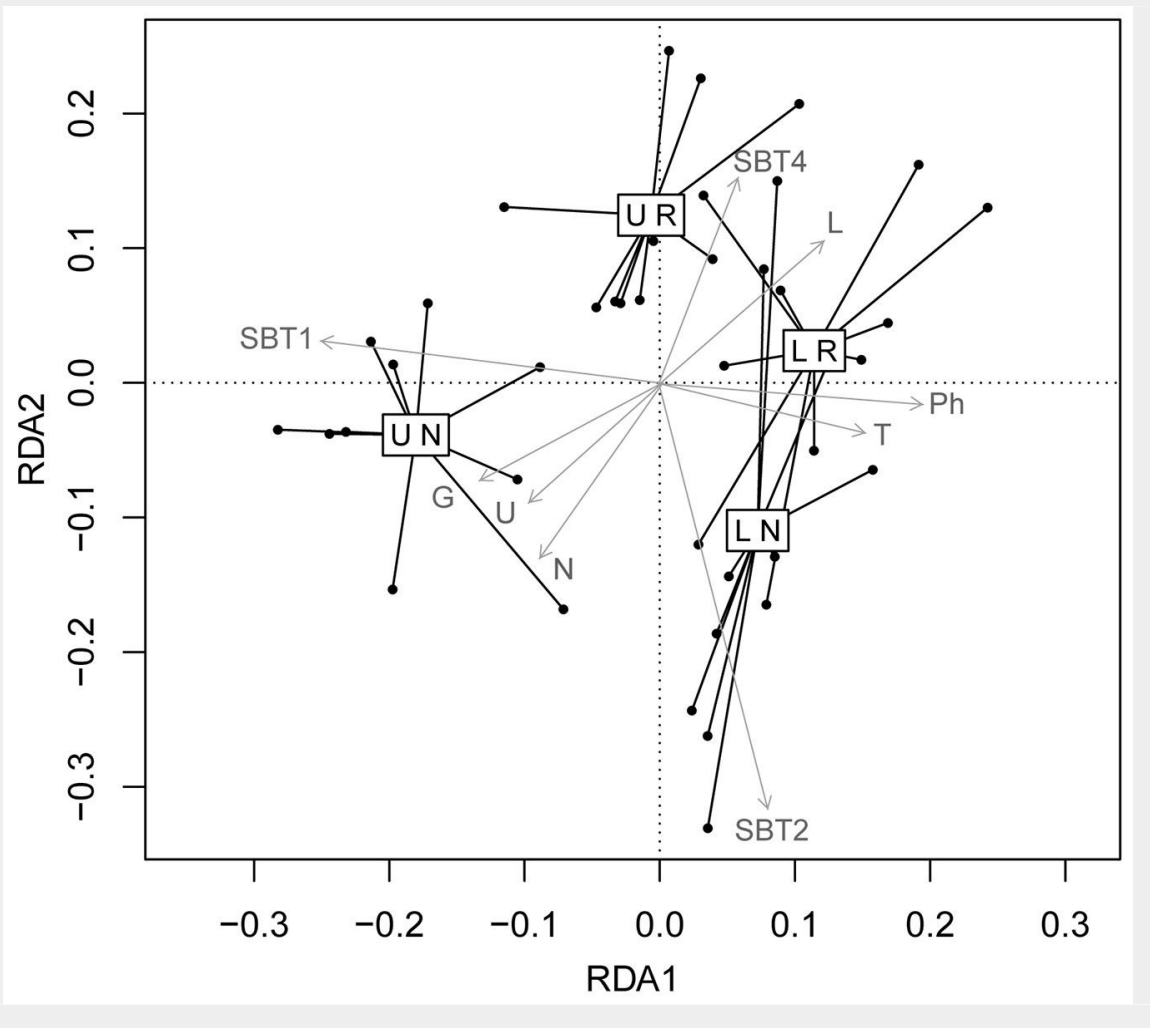

\section{Discussion}

The natural forests at high altitude (1100$1700 \mathrm{~m}$ a.s.l.) on the central Apennines, when compared to lower elevation forests (700-1100 $\mathrm{m}$ a.s.l.), showed a strong reduction of species richness (46\%), and a consequent increase in compositional diversification in terms of species (i.e., LCBD), with an ecological trait turnover. Contrastingly, no significant changes with altitude were observed in the studied pine plantations along the same altitudinal gradient.

Reductions in plant species richness with increasing altitude have been previously reported for natural forests in the Apennines (Scolastri et al. 2014), and this is in agreement with studies carried out at the global level (Rahbek 1995). Such reductions can be considered the result of the interactions between the abiotic component (environmental filter sensu stricto - Kraft et al. 2015), in particular the temperature as the main driver associated with altitude (Körner 2007), and the biotic component ( $\mathrm{Ca}$ dotte \& Tucker 2017), mainly represented by the forest canopy. Indeed, it has been shown that the microclimate occurring under the canopy is determined by the coverage, structure and type of the tree layers, and it is one of the main factors responsible for the floristic and compositional richness of forests (Greiser et al. 2018). In this study, the variation along the altitudinal gradient in the microclimatic conditions due to differences in tree cover (Ostrya carpinifolia mixed tree forest at lower elevations vs. Fagus sylvatica tree forest at higher altitude) might have contributed to the progressive selection of the understorey species, and therefore to the floris- tic turnover. It is well known that Fagus stands provide more deep shade in comparison to other deciduous trees, such as Quercus and Ostrya, and that an increasing beech proportion leads to a decreasing species diversity (Mölder et al. 2008). The Fagus shading effect is confirmed in the present study by the presence of shade-tolerant sciophilous herbaceous species (based on the Ellenberg's indicator value for light), such as Adoxa moschatellina and Cephalanthera damasonium, which were more frequent in Fagus sylvatica stands than in Ostrya carpinifolia forests at lower elevation.

The high species richness and the almost unchanged floristic composition of the mature pine plantations along the studied altitudinal gradient are in contrast with the findings of Gómez-Aparicio et al. (2009) for younger pine plantations (30-50 years old). This might be likely due to the different ages of the analyzed pine plantations, and therefore to different microclimatic and shade conditions occurring under the pine canopy. The architecture of the wide and open crown that is typical of Pinus nigra mature individuals ( $>80$ years - Van Haverbeke 1986) was associated with the low tree cover (Tab. S1 in Supplementary material), which allowed light transmission to the understorey, thus promoting the establishment of heliophilous species, such as Cytisophyllum sessilifolium, which increases the richness of the herbaceous and shrubby layers. This aspect could also have positive effects on the abundance and richness of birds, which contribute to the undergrowth dissemination, and therefore to species richness (Vallauri et al. 2002, Góm-
ez-Aparicio et al. 2009). With respect to the natural forests, the high species richness and the almost unchanged floristic composition observed in the mature pine plantations along the altitudinal gradient can also be linked to the persistence of the Pinus nigra canopy. This can have a mitigating effect on the low winter temperature of the soil, and in general on the temperature variations (Morecroft et al. 1998). This likely allows the permanence of thermophilous species even at higher altitudes (as expressed by the Ellenberg's indicator value for temperature), which are typically associated to deciduous forests of the lower zones, such as Quercus pubescens s.l. and Fraxinus ornus subsp. ornus. Further studies are needed to test the microclimate annual variation under the pine canopy by directly measuring microclimatic parameters. The abundance of SBT4 (marginal species - exotics, weeds, members of ruderal or agricultural communities - sensu Bartha et al. 2008) and in general the high frequencies of non-forest herbaceous species (mainly grasslands species) such as Cytisus spinescens and Sesleria nitida might be a legacy of the previous land cover (secondary grassland) on the understory of mature pine plantations (at low and high altitudes). Nevertheless, these grassland species (non-forest species included in SBT3, sensu Bartha et al. 2008) are frequently found in neighbouring natural forests (see Tab. S2 in Supplementary material). This is an indicator of disturbance for the natural forests, and can be considered the consequence of past anthropogenic impacts that especially affected the south-facing slopes of the Apennines (Bonanomi et al. 2018). 


\section{Conclusions}

This study investigated pine plantations and natural forests along two distinct altitude trends in the Central Apennines (Italy). The afforestation by black pine was carried out about 90 years ago, and slowed the typical diversification of the stands at the community level, by mitigating the effects of increased altitude, which is typical in natural forests. Indeed, mature pine plantations allow the presence of many heliophilous and thermophilous species up to $1400 \mathrm{~m}$ to $1500 \mathrm{~m}$ a.s.l., which are usually distributed at lower altitudes. The lack of differences in species composition of pine plantations along the altitude gradient may be attributed to the buffering effect of pine canopy on the microclimatic conditions in the understorey. The open architecture of the mature pine canopy associated with the low cover of the tree layer may have favoured the establishment of heliophilous species.

The mature pine plantations reduced the beta diversity of the forest landscape and the compositional diversification that usually occurs in natural forests, especially at high altitudes. Furthermore, in contrast to the natural forests, the average contribution to the beta diversity of pine plantations was not affected by altitude.

\section{List of abbreviations}

ALT: altitude; ANOVA: analysis of variance; LCBD: local contributions to beta diversity; MANOVA: multivariate analysis of variance; ORIG: forest origin; RDA: redundancy analysis; SBT: social behaviour types; SBT1: beech forest specialist species; SBT2: forest generalist species; SBT3: no forest species; SBT4: marginal species - exotics, weeds, members of ruderal or agricultural communities.

\section{Author contributions}

$M A, S P$, and $C O$ developed the methodology and sampling design. MA, SB, GT and $\mathrm{CO}$ conducted the vegetation data collection. SB revised the floristic taxa list. SP conducted the data analyses. MA, SP, GT and $\mathrm{CO}$ provided critical revision of the data interpretation. MA, SP, CO wrote the manuscript. All of the authors have approved the final version of the manuscript.

\section{Disclosure statement}

The authors declare that they have no conflicts of interest.

\section{Funding}

This study did not receive any specific grant from funding agencies in the public, commercial, or not-for-profit sectors.

\section{References}

Allegrezza M, Ballelli S, Mentoni M, Olivieri M, Ottaviani C, Pesaresi S, Tesei G (2013). Biodiversity in the Sibillini Mountain range (Sibillini National Park, central Apennines): the example of Piè Vettore. Plant Sociology 50: 57-89. [online] URL: http://www.researchgate.net/publication/
289907820

Allegrezza M, Ballelli S, Ottaviani C, Tesei G (2014). Notulae alla Checklist della flora vascolare italiana. Notula (2079) Goodyera repens (L.) [Notulae to the Checklist of the Italian vascular flora. Notula (2079) Goodyera repens (L.)]. Informatore Botanico Italiano 46 (2): 270-271. [in Italian]

Amorini E, Fabbio G (1992). La gestione dei rimboschimenti con pino nero [The management of black pine plantations]. Monti e Boschi XLIII (4): 27-29. [in Italian]

Anderson MJ (2006). Distance-based tests for homogeneity of multivariate dispersions. Biometrics 62 (1): 245-253. - doi: 10.1111/j.1541-0420. 2005.00440.x

Baiocco M, Casavecchia S, Biondi E, Pietracaprina A (1996). Indagini geobotaniche per il recupero del rimboschimento del Monte Conero (Italia centrale). [Geobotanical investigations for the restoration of the Monte Conero forest plantation (central Italy)]. Documents Phytosociologiques XVI: 387-425. [in Italian]

Barlow J, Gardner TA, Araujo IS, Avila-Pires TC, Bonaldo AB, Costa JE, Esposito MC, Ferreira LV, Hawes J, Hernandez MIM, Hoogmoed MS, Leite RN, Lo-Man-Hung NF, Malcolm JR, Martins MB, Mestre LAM, Miranda-Santos R, Nunes-Gutjahr AL, Overal WL, Parry L, Peters SL, RibeiroJunior MA, Da Silva MNF, Da Silva Motta C, Peres CA (2007). Quantifying the biodiversity value of tropical primary, secondary, and plantation forests. Proceedings of the National Academy of Sciences USA 104: 18555-18560. - doi: 10.1073/pnas.0703333104

Bartha S, Merolli A, Campetella G, Canullo R (2008). Changes of vascular plant diversity along a chronosequence of beech coppice stands, central Apennines, Italy. Plant Biosystems 142 (3): 572-583. - doi: 10.1080/1126350080 2410926

Bartolucci F, Peruzzi L, Galasso G, Albano A, Alessandrini A, Ardenghi NMG, Astuti G, Bacchetta G, Ballelli S, Banfi E, Barberis G, Bernardo L, Bouvet D, Bovio M, Cecchi L, Di Pietro R, Domina G, Fascetti S, Fenu G, Festi F, Foggi B, Gallo L, Gottschlich G, Gubellini L, Iamonico $D$, Iberite $M$, Jiménez-Mejías $P$, Lattanzi $E$, Marchetti D, Martinetto E, Masin RR, Medagli $P$, Passalacqua NG, Peccenini S, Pennesi R, Pierini B, Poldini L, Prosser F, Raimondo FM, Roma-Marzio F, Rosati L, Santangelo A, Scoppola A, Scortegagna S, Selvaggi A, Selvi F, Soldano A, Stinca A, Wagensommer RP, Wilhalm T, Conti F (2018). An updated checklist of the vascular flora native to Italy. Plant Biosystems 152 (2): 179-303. - doi: 10.1080/11263504.2017.14199 96

Benkman CW, Parchman TL (2009). Coevolution between crossbills and black pine: the importance of competitors, forest area, and resource stability. Journal of Evolutionary Biology 22: 942-953. - doi: 10.1111/j.1420-9101.2009.01703.x Biondi E, Blasi M, Allegrezza M, Anzellotti I, Azzella MM, Carli E, Casavecchia S, Copiz R, Del Vico E, Facini L, Galdenzi D, Gasparri R, Lasen C, Pesaresi S, Poldini L, Sburlino G, Taffetani F, Vagge I, Zitti S, Zivkovic L (2014). Plant communities of Italy: the vegetation prodrome. Plant Biosystems 148 (4): 728-814. - doi: 10.1080/1126 3504.2014.948527
Blasi C (2010). La vegetazione d'Italia [The vegetation of Italy]. Palombi and Partner S.r.I., Roma, Italy, pp. 540. [in Italian]

Borcard D, Gillet F, Legendre P (2011). Numerical ecology with R. Springer, New York, USA, pp. 44. [online] URL: http://books.google.com/boo ks?id=p1NSDwAAQBAJ

Bonanomi G, Rita A, Allevato E, Cesarano G, Saulino L, Di Pasquale G, Saracino A (2018). Anthropogenic and environmental factors affect the tree line position of Fagus sylvatica along the Apennines (Italy). Journal of Biogeography 45 (11): 2595-2608. - doi: 10.1111/jbi.13408

Braun-Blanquet J (1928). Pflanzen-soziologie [Plant sociology]. Springer, Berlin, Germany, pp. 330.

Bremer LL, Farley KA (2010). Does plantation forestry restore biodiversity or create green deserts? A synthesis of the effects of land-use transitions on plant species richness. Biodiversity Conservation 19: 3893-3915. - doi: $10.1007 /$ s10531-010-9936-4

Brockerhoff EG, Jactel H, Parrotta JA, Quine CP, Sayer J (2008). Plantation forests and biodiversity: oxymoron or opportunity? Biodiversity Conservation 17: 925-951. - doi: 10.1007/s10531-0 08-9380-x

Cadotte MW, Tucker CM (2017). Should environmental filtering be abandoned? Trends in Ecology and Evolution 32 (6): 429-437. - doi: 10.1016/ j.tree.2017.03.004

Cantiani P, lorio G, Pelleri F (2005). The effects of thinning in black pine stands (Pettenaio, Perugia). Forest@2 (2): 207-216. [in Italian with English abstract] - doi: 10.3832/eforo292-0020207

Cantiani P, Di Salvatore U, Romano R (2018). The silviculture of black pine plantations: analysis of Italian regional legislation. Forest@ 15: 99-111. [in Italian with English abstract] - doi: 10.3832/ efor2985-015

Carnus JM, Parrotta J, Brockerhoff E, Arbez M, Jactel H, Kremer A, Lamb D, O'Hara K, Walters $B$ (2006). Planted forests and biodiversity. Journal of Forestry 104: 65-77. [online] URL: http:// academic.oup.com/jof/article/104/2/65/4599206 Chiarucci A, De Dominicis V (1995). Effects of pine plantations on ultramafic vegetation of central Italy. Israel Journal of Plant Sciences 43: 7-20. - doi: 10.1080/07929978.1995.10676586

Ellenberg H, Weber HE, Düll R, Wirth V, Werner W, Paulissen D (1992). Zeigerwerte von pflanzen in Mitteleuropa [Indicator values of plants in Central Europe]. Scripta Geobotanica 18: 1248. [in German]

FAO (2006). Global planted forest thematic study: results and analysis (Del Lungo A, Ball J, Carle J eds). Planted Forests and Trees Working Paper 38, FAO, Rome, Italy, pp. 168. [online] URL: http://www.fao.org/forestry/12139-03441d 093f070ea7d7c4e3ec3f306507.pdf

Forest Europe (2015). State of Europe's forests 2015. Ministerial Conference on the Protection of Forests in Europe, Forest Europe Liaison Unit, Madrid, Spain, pp. 314. [online] URL: http://www.foresteurope.org/docs/fullsoef2015 .pdf

Geldenhuys CJ (1997). Native forest regeneration in pine and eucalypt plantations in Northern Province, South Africa. Forest Ecology and Management 99: 101-115. - doi: 10.1016/S03781127(97)00197-7 
Gómez-Aparicio L, Zavala M, Francisco Bonet J, Zamora R (2009). Are pine plantations valid tools for restoring Mediterranean forests? An assessment along abiotic and biotic gradients. Ecological Applications 19: 2124-2141. - doi: 10.1890/08-1656.1

Greiser C, Meineri E, Luoto M, Ehrlén J, Hylander K (2018). Monthly microclimate models in a managed boreal forest landscape. Agricultural and Forest Meteorology 250: 147-158. - doi: 10.1016/j.agrformet.2017.12.252

Hrivnák R, Gömöry D, Slezák $M$, Ujházy K, Hédl $R$, Jarčuška $B$, Ujházyová $M$ (2014). Species richness pattern along altitudinal gradient in Central European beech forests. Folia Geobotanica 49 (3): 425-441. - doi: 10.1007/s12224-013-9174-0

INFC (2007). Le stime di superficie 2005 - Prima parte. Inventario nazionale delle foreste e dei serbatoi forestali di carbonio [Area estimation 2005 - First part. National inventory of forest and carbon forest accumulations] (Tabacchi G, De Natale F, Di Cosmo L, Floris A, Gagliano C, Gasparini P, Genchi L, Scrinzi G, Tosi V eds). MiPAF - Corpo Forestale dello Stato - Ispettorato Generale, CRA -ISAFA, Trento, Italy. [in Italian] [online] URL: http://www.sian.it/inventariofor estale/jsp/01tabelle_superficie.jsp

Körner C (2007). The use of "altitude" in ecological research. Trends in Ecology and Evolution 22 (11): 569-574. - doi: 10.1016/j.tree.2007.09.006 Kraft NJ, Adler PB, Godoy O, James EC, Fuller S, Levine JM (2015). Community assembly, coexistence and the environmental filtering metaphor. Functional Ecology 29 (5): 592-599. - doi: 10.1111/1365-2435.12345

Kunstler G, Tuiller W, Curt T, Bouchaud M, Jouvie R, Deruette F, Lepart J (2007). Fagus sylvatica L. recruitment across a fragmented Mediterranean landscape, importance of long distance effective dispersal, abiotic conditions and biotic interactions. Diversity and Distributions 13 (6): 799-807. - doi: 10.1111/j.1472-4642.2007.00404.x Legendre P, De Cáceres M (2013). Beta diversity as the variance of community data: dissimilarity coefficients and partitioning. Ecology Letters 16: 951-963. - doi: 10.1111/ele.12141

Mölder A, Bernhardt-Römermann M, Schmidt W (2008). Herb-layer diversity in deciduous forests: raised by tree richness or beaten by beech? Forest Ecology and Management 256: 272-281. - doi: 10.1016/j.foreco.2008.04.012

Morecroft MD, Tylor ME, Oliver HR (1998). Air and soil microclimates of deciduous woodland compared to an open site. Agricultural and Forest Meteorology 90: 141-156. - doi: 10.1016/So16 8-1923(97)00070-1

Mosandl R, Küssner R (1999). Conversion of pure pine and spruce forests into mixed forests in eastern Germany: some aspects of silvicultural strategy. In: "Management of mixed-species forest: Silviculture and economics" (Olsthoorn AFM, Bartelink HH, Gardiner JJ, Pretzsch H, Hekhuis HJ, Franc A eds). IBN scientific contributions 15, Institute for Forestry and Nature Research (IBN-DLO), Wageningen, Netherlands, pp. 208-218. [online] URL: http://media tum.ub.tum.de/doc/738694/file.pdf

Nocentini S (1999). La gestione dei rimboschimenti tra selvicoltura e arboricoltura da legno [The management of forest plantation between silviculture and wood arboriculture]. In: "Nuove frontiere nella gestione forestale" (Ciancio O ed). Accademia Italiana di Scienze Forestali, Firenze, Italy, pp. 117-129. [in Italian] Olthoff A, Martínez-Ruiz C, Alday JG (2016). Distribution patterns of forest species along an Atlantic-Mediterranean environmental gradient: an approach from forest inventory data. Forestry 89 (1): 46-54. - doi: 10.1093/forestry/cpvo 31

Ottaviani C, Tesei G, Ballelli S, Iorio G, Montecchiari S, Allegrezza M (2015). Vegetation dynamics in Pinus nigra Arnold subsp. nigra 100 years after reforestation: two case studies in the central Apennines. Plant Sociology 52: 7994.

Pesaresi S, Galdenzi D, Biondi E, Casavecchia S (2014). Bioclimate of Italy: application of the worldwide bioclimatic classification system. Journal of Maps 10 (4): 538-553. - doi: 10.1080/ 17445647.2014.891472

Pesaresi S, Biondi E, Casavecchia S (2017). Bioclimates of Italy. Journal of Maps 13 (2): 955-960. - doi: 10.1080/17445647.2017.1413017

Pignatti S, Menegoni P, Pietrosanti S (2005). Bioindicazione attraverso le piante vascolari. Valori di indicazione secondo Ellenberg (Zeigerwerte) per le specie della Flora d'Italia [Biondication through vascular plants. Indication values according to Ellenberg (Zeigerwerte) for the flora species of Italy]. Braun-Blanquetia 39: 1-97. [in Italian]

Pignatti S (1982). Flora d'Italia [Flora of Italy]. Edagricole, Bologna, voll. 1-3. [in Italian]

Rahbek C (1995). The elevational gradient of species richness: a uniform pattern? Ecography 18
(2): 200-205. - doi: 10.1111/j.1600-0587.1995.tboo 341. $\mathrm{x}$

Rivas-Martínez S, Sáenz SR, Penas A. (2011). Worldwide bioclimatic classification system. Global Geobotany 1: 1-634.

Sabatini FM, Jiménez-Alfaro B, Burrascano $S$, Lora A, Chytry M (2018). Beta-diversity of central European forests decreases along an elevational gradient due to the variation in local community assembly processes. Ecography 41 (6): 1038-1048. - doi: 10.1111/ecog.02809

Scolastri A, Cancellieri L, locchi M, Cutini M (2014). Patterns of floristic variation on a montane beech forest in the central Apennines (central Italy). Plant Sociology 51: 69-82. [online] URL: http://www.riservaduchessa.it/pub blicazioni/2014_Scolastri_et_al_Floristic_variati on beech forest Duchessa.pdf

Sharma CM, Suyal S, Gairola S, Ghildiyal SK (2009). Species richness and diversity along an altitudinal gradient in moist temperate forest of Garhwal Himalaya. Journal of American Science 5 (5): 119-128. [online] URL: http://www. researchgate.net/publication/228591101

Vallauri DR, Aronson J, Barbéro M (2002). An analysis of forest restauration on badlands in the southwestern Alps. Restoration Ecology 10: 16-26. - doi: 10.1046/j.1526-100X.2002.10102.x Van Haverbeke DF (1986). Twenty-year performance of Scotch, European black (Austrian), red, and jack pines in eastern Nebraska. Research Paper RM-267, USDA Forest Service, Rocky Mountain Forest and Range Experiment Station, Fort Collins, CO, USA, pp. 14.

Vazquez-García JA, Givnish TJ (1998). Altitudinal gradients in tropical forest composition, structure and diversity in the Sierra de Manantlán. Journal of Ecology 86: 999-1020. - doi: 10.1046/ j.1365-2745.1998.00325.x

Zerbe S (2002). Restoration of natural broadleaved woodland in Central Europe on sites with coniferous forest plantations. Forest Ecology and Management 167: 27-42. - doi: 10.1016/ S0378-1127(01)00686-7

\section{Supplementary Material}

Tab. S1 - Pinus nigra forestation data.

Tab. S2 - List of the species and their biological forms.

Link: Allegrezza_3215@supploo1.pdf 